\title{
PROTECTIVE AND CURATIVE ACTIVITY OF AZOXYSTROBIN AND ITS MIXTURES AGAINST POWDERY MILDEW ON SQUASH
}

Nosehy $^{1^{*}}$ T.V., Abd Elmeged ${ }^{1}$ M.E., Dahroug ${ }^{1}$ S.A. and Marian S. Thabet ${ }^{2}$

1- Plant Protection Dept., Fac. of Agric., Ain Shams Univ., P.O. Box 68, Hadayek Shobra 11241, Cairo, Egypt

2- Plant Pathology Dept., Fac. of Agric., Ain Shams Univ., P.O. Box 68, Hadayek Shobra 11241, Cairo, Egypt

${ }^{*}$ Corresponding author: tamervicoo@gmail.com

Received 26 September, 2019

Accepted 3 November, 2019

\begin{abstract}
Squash is one of the important crops of the cucurbits family and powdery mildew causes less yield every year, Strobilurin group are common fungicides used to control powdery mildew disease. In addition, Strobilurin is more safe for humans and the environment because it is derived from a natural fungicidal source (the production of the active ingredients are achieved by wood-rotting of Strobilurus tenacellus). Strobilurin contains a group of active ingredients that control various diseases such as powdery and downy mildew on cucumber, grapes, and watermelon, early blight and late blight on tomatoes and potatoes, scab on apple and others. This study focuses on the effectiveness of protective and curative applications of Azoxystrobin as one of the active ingredients of Strobilurin group alone and mixtures against powdery mildew on squash. The induction of resistance of plants against powdery mildew by using $\mathrm{KH}_{2} \mathrm{PO}_{4}$ and $\mathrm{K}_{2} \mathrm{HPO} 4$, protective and curative applications. The tested compounds against powdery mildew on squash at protective method were Azoxystrobin mixture with Difenoconazole $83.3 \%$, Azoxystrobin mixture with Tebuconazole $76.6 \%$, Azoxystrobin alone $70.7 \%$, Difenoconazole $62.3 \%$, Tebuconazole $55.9 \%, \mathrm{~K}_{2} \mathrm{HPO}_{4} 16.7 \%$ and $\mathrm{KH}_{2} \mathrm{PO}_{4}$ $10.8 \%$. The curative effectiveness of the tested products against powdery mildew on squash was as follows Azoxystrobin mixture with Difenoconazole $69.3 \%>$ Azoxystrobin mixture with Tebuconazole $61.2 \%>$ Azoxystrobin alone $57.6 \%>$ Difenoconazole $44.2 \%>$ Tebuconazole $42.7 \%>\mathrm{K}_{2} \mathrm{HPO}_{4}$ $12.1 \%>\mathrm{KH}_{2} \mathrm{PO}_{4}$ 7.4\%. Accordingly, Azoxystrobin alone and its mixtures were most effective against powdery mildew on squash compared to Difeno-
\end{abstract}

conazole, Tebuconazole, $\mathrm{K}_{2} \mathrm{HPO}_{4}$ and $\mathrm{KH}_{2} \mathrm{PO}_{4}$ alone in both protective and curative applications. However the protective method was more effective compared to the curative method and the mixture of Azoxystrobin with Difenoconazole was more effective compared to all tested treatments followed by the mixture of Azoxystrobin with Tebuconazole and both treatments were slightly better or comparable to Azoxystrobin alone. In addition, the foliar application by $\mathrm{KH}_{2} \mathrm{PO}_{4}$ and $\mathrm{K}_{2} \mathrm{hPO}_{4}$ was inferior in activity to resistant powdery mildew infection under the field conditions.

Keywords: Azoxystrobin, Strobilurin, Powdery mildew, Curative, Protective, Activity, Cucurbits

\section{INTRODUCTION}

Azoxystrobin is one of the most important active ingredient of the fungicide Strobilurin group. It is leading the worldwide fungicides possessing broad spectrum systemic activity against the four major disease classes of pathogenic fungi. The strobilurin group of fungicides was detected by derivation of b-methoxyacrylic acid from natural fungicidal group and the production of it by woodrotting of Strobilurus tenacellus. The mode of action of the strobilurins against fungi is their ability of inhibit mitochondrial respiration by binding thesecalled Qo site of cytochrome b. located in cytochrome bc1complex and that part of the inner of mitochondrial membrane of fungi. This inhibition blocks the electrons transfer between cytochrome $\mathrm{b}$ and cyto-chrome $\mathrm{c} 1$ that causes disruption of the fungus energy cycle, within halting the production of ATP (Bartlett et al 2002). Cucurbitaceae is an important family, which supply humans with a lot of 
edible products and useful fibers. Plants of cucurbits family are very similar in vegetative development, but they have a high genetic diversity for fruit shape and characteristics, resulting in a variety range of uses (Bisognin, 2002). Powdery mildew disease causes devastation in cucurbits and yield can decline with increase of disease severity (Lamsa, 2011). However the plants may resist the disease if they have good vegetative state by using some non-chemical products like $\mathrm{KH}_{2} \mathrm{PO}_{4}$ and $\mathrm{K}_{2} \mathrm{HPO}_{4}$. The foliar fertilizers of phosphates and potassium salts are convenient to use with a potential useful impact on control the disease (Reuveni et al 1995). Powdery mildew caused by Erysiphe cichoracearum (Bardin, 1999) and Podosphaera fusca (synonyms: P. xanthii, Sphaerotheca fulginea and S. fusca), (Janousek et al 2009, McGrath and Thomas 1996, Pérez-García et al 2009, Alejandro, 2009). Squash is a member of cucurbits family and the powdery mildew causes less yield. The objective of the study is to measure the effectivenss of Azoxystrobin and its mixtures against powdery mildew on squash and determine the induction of resistance of plants against powdery mildew by using $\mathrm{KH}_{2} \mathrm{PO} 4$ and $\mathrm{K}_{2} \mathrm{HPO}_{4}$.

\section{MATERIALS AND METHODS}

This study was carried out during two growing seasons 2015/2016 and 2017/2018 under open field conditions at Katta, Qalyubyia Governorate, Egypt.

\section{Squash cultivars used}

Local variety of squash "Eskandrany" was sown in autumn from July to August. (Agricultural Research and Extension Center)

\section{Plantation techniques}

Seeds were directly sown in soil ( $3 \mathrm{~kg} / \mathrm{acre})$, at $40 \mathrm{~cm}$ intervals between plants, $1 \mathrm{~m}$ row space between rows and the maintenance application against Whitefly and Aphid were applied by Actara $25 \% \mathrm{WG}$ and Vertemic $1.8 \%$ EC according to the recommendation of the Ministry of Agriculture.

\section{Plot size and replicates number}

A randomized block design with three replicates was adopted for two seasons. Each replicate contained three plots, the plot size was $15 \mathrm{~m}^{2}$. Each plot consisted of three rows, each row was five meters length and one meter width and plants distance was $40 \mathrm{~cm}$.

\section{Applications and Type of soil}

The first season was in sandy soil at Katta Governorate, curative application after infestation was applied in October/ November of 2015 and the second season was in clay soil at Qalyubyia Governorate, protective application before infestation was applied in October of 2018. The number of applications was three times according to local practice. The application interval was ten days, depending on the disease development in the field.

\section{Application equipment}

The applications were achieed by using Back sprayer, hollocn nozzle, size 1.5 and the pressure of spray was $1.5-2$ bars.

\section{Treatments}

Seven treatments were applied: Azoxystrobin + Difenoconazole 325 SC (1), Azoxystrobin + Tebuconazole 320 SC (2), Azoxystrobin 250 SC (3), Difenoconazole 250 SC (4), Tebuconazole 430 SC (5), $\mathrm{K}_{2} \mathrm{HPO}_{4}$ (6) and $\mathrm{KH}_{2} \mathrm{PO}_{4}$ (7), Azoxystrobin (purity > 97\%), Difenoconazole (purity > 99\%). These products alone and mixture were purchased from Syngenta Ago Co, Azoxystrobin + Tebuconazole purchased from AAKO BV Co. and Tebuconazole produced from Jiangsu Rotam Chemistry Co., Ltd (purity > 95.7\%).

\section{Evaluations}

Disease severities were evaluated from 2 to 3 leaves taken from plants grown in middle row selected randomly. The evaluations were made each 5 days and before applications for all plots. Disease severity was recorded 20 days after the last application with the following scale: $(0)=$ no symptoms, $(1)=0 \%$ to $5 \%,(3)=6 \%$ to $10 \%,(5)=11 \%$ to $20 \%,(7)=21 \%$ to $40 \%$, and (9) = more than $40 \%$ from the natural infected surface area of the leaf covered with mildew, produced from 25 leaves per plot (75 leaves per treatment). The disease index for each treatment was calculated using the following formula:

$$
\mathrm{DI}=\frac{\left(\sum_{i=0}^{9} N_{i} \times i\right)}{\sum_{i=0}^{9} N_{i} \times 9} \times 100
$$

Where $(i)$ is the disease severity (0 to 9$)$ and $(N i)$ indicates the number of leaves with the severity of (i). 

Powdery Mildew on Squash

Disease control was calculated as follows (Qingrong Peng et al 2017):

$\mathrm{DC}(\%)=\left(\frac{\mathrm{Dl}_{\mathrm{UTCO}}-\mathrm{Dl}_{\mathrm{CT} 1}}{\mathrm{Dl}_{\mathrm{UTCO}}}\right) \times 100$
Where (UTCO) indicates the disease severity of the untreated control before the first treatment and (CT1) stands for the disease severity of any treatment after the last treatment.

Table 1. Treatments list of commercial products which used for the field trials and their rates

\begin{tabular}{|c|c|c|c|c|}
\hline $\begin{array}{c}\text { Treatment } \\
\text { number }\end{array}$ & Treatments & Formulation & $\begin{array}{c}\text { Rates } \\
\text { (g or } \mathbf{~ m l} / \mathbf{~ h l})\end{array}$ & $\begin{array}{c}\text { Active } \\
\text { ingredients/ hl* }\end{array}$ \\
\hline 1 & Azoxystrobin (AZ) + Difenoconazole (DFZ) & $325 \mathrm{SC}$ & 50 & $10 \mathrm{AZ}+6.25 \mathrm{DFZ}$ \\
2 & Azoxystrobin (AZ) + Tebuconazole (TBZ) & $320 \mathrm{SC}$ & 100 & $12 \mathrm{AZ}+20 \mathrm{TBZ}$ \\
3 & Azoxystrobin & 250 SC & 50 & 12.5 \\
4 & Difenoconazole & 250 SC & 50 & 12.5 \\
5 & Tebuconazole & 430 SC & 35 & 81.3 \\
6 & K2HPO4 & - & 100 & - \\
7 & KH2PO4 & - & 100 & - \\
\hline
\end{tabular}

*Hectoliter $(\mathrm{hl})=100$ liter of water

\section{RESULTS AND DISCUSSION}

1. Effectiveness of Azoxystrobin alone and in mixtures compared to other treatments against powdery mildew on squash

Azoxystrobin alone and in mixture were effective against powdery mildew in both protective and curative applications and they were better in activity compared to Difenoconazole, Tebuconazole, $\mathrm{K}_{2} \mathrm{HPO}_{4}$ and $\mathrm{KH}_{2} \mathrm{PO}_{4}$. However the mixture of Azoxystrobin with Difenoconazole was superior compared to all tested treatments and the mixture of Azoxystrobin with Tebuconazole was slightly better in activity compared to Azoxystrobin alone (Tables 2 \& 3).

Table 2. Mean \% effectiveness of Azoxystrobin alone and in mixtures as curative application compared to other treatments against powdery mildew on squash.

\begin{tabular}{|c|c|}
\hline Treatments & $\%$ Efficacy \\
\hline Azoxystrobin + Difenoconazole & $69.3^{a} \pm 3.2$ \\
\hline Azoxystrobin + Tebuconazole & $61.2^{\mathrm{b} \pm 3.2}$ \\
\hline Azoxystrobin & $57.6^{\mathrm{b}} \pm 3.3$ \\
\hline Difenoconazole & $44.2^{c \pm 3.0}$ \\
\hline Tebuconazole & $42.7^{c} \pm 3.3$ \\
\hline $\mathrm{K}_{2} \mathrm{HPO}_{4}$ & $12.1^{d \pm 2.1}$ \\
\hline $\mathrm{KH}_{2} \mathrm{PO}_{4}$ & $7.4^{\mathrm{d} \pm 1.9}$ \\
\hline F value & $438.33^{* *}$ \\
\hline LSD & 5.5408 \\
\hline
\end{tabular}

The results of the curative method in Table (2) showed that the effectiveness of Azoxystrobin mixture with Difenoconazole was $69.3 \%$ against powdery mildew on squash. However, Azoxystrobin mixture with Tebuconazole was $61.2 \%$ effictive and both treatments were better in activity compared to Azoxystrobin alone $57.6 \%$ efficacy. In addition Azoxystrobin alone and in mixture showed better in effectiveness compared to the Triazols Difenoconazole $44.2 \%$ and Tebuconazole $42.7 \%$. $\mathrm{K}_{2} \mathrm{HPO}_{4}$ $12.1 \%$ efficacy, $\mathrm{KH}_{2} \mathrm{PO}_{4} 7.4 \%$ and they were efficacy were inferior in their control against powdery mildew on squash compared to all tested treatments.

Table 3. Mean \% effectiveness of Azoxystrobin alone and mixture as protective application compared to other treatments against powdery mildew on squash.

\begin{tabular}{|c|c|}
\hline Treatments & \% Effectiveness \\
\hline Azoxystrobin + Difenoconazole & $83.3^{\mathrm{a} \pm 3.2}$ \\
Azoxystrobin + Tebuconazole & $76.6^{\mathrm{ab} \pm 3.2}$ \\
Azoxystrobin & $70.7^{\mathrm{b} \pm 3.3}$ \\
Difenoconazole & $62.3^{\mathrm{c} \pm 3.0}$ \\
Tebuconazole & $55.9^{\mathrm{c} \pm 3.3}$ \\
$\mathrm{~K}_{2} \mathrm{HPO}_{4}$ & $16.7^{\mathrm{d} \pm 2.1}$ \\
$\mathrm{KH}_{2} \mathrm{PO}_{4}$ & $10.8^{\mathrm{d} \pm 1.9}$ \\
\hline F value & $313.31^{\star \star}$ \\
\hline LSD & 7.8575 \\
\hline
\end{tabular}


The result of protective method in Table (3) showed that the effectiveness of Azoxystrobin mixture with Difenoconazole was $83.3 \%$ against powdery mildew on squash. However, Azoxystrobin mixture with Tebuconazole was $76.6 \%$ effective and both treatments were better compared to Azoxystrobin alone $70.7 \%$. In addition Azoxystrobin alone and mixture was more effective compared to the Triazoles Difenoconazole $62.3 \%$ and Tebuconazole $55.9 \%$. $\mathrm{K}_{2} \mathrm{HPO}_{4}$ 16.7\% effective and $\mathrm{KH}_{2} \mathrm{PO}_{4} \quad 10.8 \%$ and were least effective against powdery mildew on squash compared to all tested treatments.

Several authors evaluated the effectiveness of Azoxystrobin alone and in mixtures against powdery mildew on cucurbits. For example Azoxystrobin (Amistar 25 SC) showed successfully arrest of disease progression compared to Mancozeb at $1 \mathrm{~kg} / \mathrm{ha}$ and Carbendazim at $500 \mathrm{~g} / \mathrm{ha}$ against downy mildew and powdery mildew on cucumber (Anand et al 2008). Azoxystrobin 25 SC at $0.1 \%$, four applications at seven days interval was better in activity, followed by four applications of Carbendazim 50 WP at 0.1 per cent, followed by Azoxystrobin 25 SC at $0.08 \%$ and Penconazole $10 \mathrm{EC}$ at $0.05 \%$ against powdery mildew (Erysiphe cichoracearum) of cucurbits from initial onset of infection (Ilhe et al 2007). Also the mixture of Azoxystrobin showed more effectiveness compared to Azoxystrobin alone. Other authors showed similar results of Azoxystrobin mixture against powdery mildews of sugar beet. The mixtures treatments of Azoxystrobin and Pyraclostrobin with Difenoconazole or Cyproconazole showed better control compared to single applications for each mixture of them against powdery mildew on sugar beet (Karaoglanidisa and Karadimosb 2006). The mixture of Azoxystrobin and Difenoconazole was more potent compared to the mixtures of each of them with Sulphur against Erysiphe betae on sugar beet because Azoxystrobin was more effective than that of Difenoconazole and both of them were more potent compared to sulphur treatment by protective and curative applications (Anesiadis et al 2003). Good control against Conidial germination of Podosphaera pannosa pathogen causing powdery mildew in a Petri plate was recorded in Difenoconazole $(85.96 \%)$ followed by Trifloxystrobin + Tebuconazole $(83.60 \%)$, Tebuconazole $(82.07 \%)$, Hexaconazole (78.99\%), Propiconazole (77.20\%) and Dinocap (71.97\%) (Kumar and Chandel (2018).

2. Protective treatment effectiveness of Azoxystrobin alone and in mixture compared to curative treatment against powdery mildew on squash plants

All treatments of protective application were highly active against powdery mildew compared to the same treatments in the curative application (Table 4), Several authors evaluated treatments of protective application compared to curative application and the results showed that curative applications of Azoxystrobin, Myclobutanil, and Pyraclostrobin against powdery mildew of watermelon were less effective compared to preventative applications (Anthony and Virginia 2004), Effective control of strobilurin against Cercospora beticola, was obtained when applied at $24 \mathrm{~h}$ after inoculation, but they were less effective when applied at $96 \mathrm{~h}$ after inoculation (Karadimos et al 2005).

Table 4. Mean \% effectiveness of protective application treatments compared to the same curative of application treatments against powdery mildew on squash

\begin{tabular}{|c|c|c|c|c|}
\hline \multirow{2}{*}{ Treatments } & \multicolumn{2}{|c|}{$\%$ Effectiveness } & \multirow{2}{*}{ F value } & \multirow{2}{*}{ LSD } \\
\cline { 2 - 3 } & Curative app. & Protective app. & & \\
\hline Azoxystrobin + Difenoconazole & $69.3^{\mathrm{a} \pm 3.2}$ & $83.3^{\mathrm{b} \pm 3.2}$ & $73.41^{\star}$ & 4.5354 \\
Azoxystrobin + Tebuconazole & $61.2^{\mathrm{a} \pm 3.2}$ & $76.6^{\mathrm{b} \pm 3.2}$ & $58.62^{\star}$ & 5.5734 \\
Azoxystrobin & $57.6^{\mathrm{a} \pm 3.3}$ & $70.7^{\mathrm{b} \pm 3.3}$ & $127.08^{\star \star}$ & 3.2245 \\
Difenoconazole & $44.2^{\mathrm{a} \pm 3.0}$ & $62.3^{\mathrm{b} \pm 3.0}$ & $96.34^{\star *}$ & 5.1233 \\
Tebuconazole & $42.7^{\mathrm{a} \pm 3.3}$ & $55.9^{\mathrm{b} \pm 3.3}$ & $44.99^{\star}$ & 5.4427 \\
$\mathrm{~K}_{2} \mathrm{HPO}_{4}$ & $12.1^{\mathrm{a} \pm 2.1}$ & $16.7^{\mathrm{a} \pm 2.1}$ & 3.23 & 5.3633 \\
$\mathrm{KH}_{2} \mathrm{PO}_{4}$ & $7.4^{\mathrm{a} \pm 1.9}$ & $10.8^{\mathrm{a} \pm 1.9}$ & 2.47 & 8.2003 \\
\hline
\end{tabular}




\section{REFERENCES}

Anand T., Chandrasekaran A., Kuttalam S.P., Senthilraja G., Raguchander T. and Samiyappan R. 2008. Effectiveness of azoxystrobin in the control of Erysiphe Cichoracearum and Pseudoperonospora Cubensis on cucumber. J. of Plant Protection Research, 48(2), 147-159.

Anesiadis T., Karaoglanidis G.S. and TzavellaKlonari K. 2003. Protective, Curative and Eradicant Activity of the Strobilurin Fungicide Azoxystrobin against Cercospora beticola and Erysiphe betae. J. Phytopathology, 151, 647-651.

Bardin M., Carlier J. and Nicot P. 1999. Genetic differentiation in the French population of Erysiphe cichoracearum, a causal agent of powdery mildew of cucurbits. Plant Pathology. 48(4), 531-540.

Bartlett D.W., Clough J.M., Godwin J.R., Hall A.A., Hamer $M$. and Parr-Dobrzanski B. 2002. The strobilurin fungicides. Pest Manag Sci., 58, 649-662.

Bisognin D.A. 2002. Origin and evolution of cultivated cucurbits. Cienc. Rural, 32(4), 715-723.

García P., Romero A.D., Fernández-Ortuño López-Ruiz D., F., De Vicente A and Torés J.A. 2009. The powdery mildew fungus Podosphaera fusca (synonym Podosphaera xanthii), a constant threat to cucurbits. Molecular Plant Pathology 10, 153-160.

Ilhe B.M., Garad B.V., Asane G.B. and Kshirsagar D.B. 2007. Chemical control of powdery mildew disease of cucumber. Agric. Sci. Digest, 27(2), 148-149.

Janousek C.N., Su H., and Gubler W.D. 2009. Control of powdery mildew on pumpkin leaves: 2008 field trial. UC Davis: Department of Plant Pathology, 1, 1-10.
Karadimos D.A., Karaoglanidis G.S. and Tzavella-Klonaric K. 2005. Biological activity and physical modes of action of the Qo inhibitor fungicides trifloxystrobin and pyraclostrobin against Cercospora beticola. Crop Protection, 24(1), 23-29.

Karaoglanidisa G.S. and Karadimosb D.A. 2006. Efficacy of strobilurins and mixtures with DMI fungicides in controlling powdery mildew in field grown sugar beet. Crop Protection, 25(9), 977-983.

Keinath A.P. and DuBose V.B. 2004. Evaluation of fungicides for prevention and management of powdery mildew on watermelon. Crop Protection, 23(1), 35-42.

Kumar V. and Chandel S. 2018. Effect of different fungicides against Podosphaera pannosa causing rose powdery mildew under greenhouse conditions. J. of Crop and Weed, 14(2), 168-173.

Lamsa K., Kim S., Jung J.H., Kim Y.S., Kim K.S. and Lee Y.S. 2011. Inhibition Effects of Silver Nanoparticles against Powdery Mildews on Cucumber and Pumpkin. Microbiology, 39(1), 26-32.

McGrath M.T., Staniszewska H., Shishkoff N. and Casella G. 1996. Fungicide sensitivity of Sphaerotheca fuliginea populations in the United States. Plant Disease 80, 697-703.

Pérez-García A., Romero D., Fernández-Ortuño D., López-Ruiz F., Vicente A.D. and Torés J.A. 2009. The powdery mildew fungus Podosphaera fusca (synonym Podosphaera xanthii), a constant threat to cucurbits. Molecular Plant Pathology 10(2), 153-160.

Reuveni M., Agapov V. and Reuveni R. 1995. Suppression of cucumber powdery mildew (Sphaerotheca fuliginea) by foliar sprays of pbospbate and potassium salts. Plant Pathology 44, 31-39. 


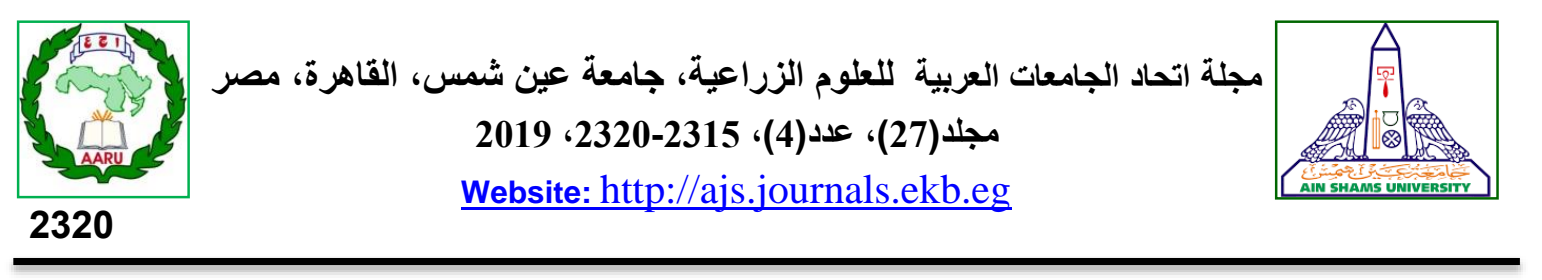

الفاعلية الوقائية والعلاجية لأزوكسيستروبين ومخاليطه ضد البياض الدقيقي على الكوسة

[184]

تامر فيكتور نصحي" - - محمد إبراهيم عبدالمجيد1 - سيد عبداللطيف دحروج1 - ماريان شكري ثابت2 2

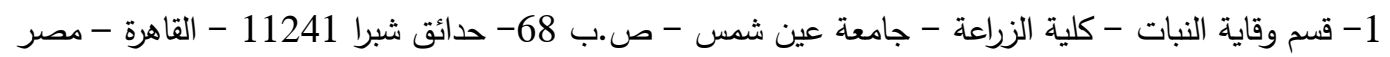

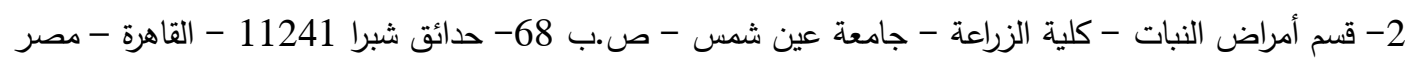

*Corresponding author: tamervicoo@gmail.com

Received 26 September, 2019

Accepted 3 November, 2019

على الكوسة مقارنة بباقى المعاملات الاخري. المعاملة

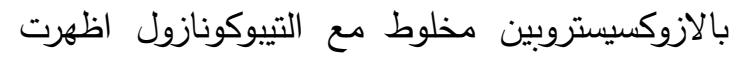

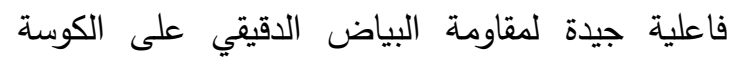

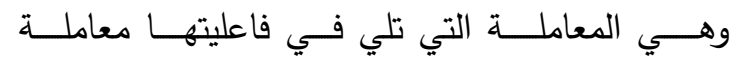

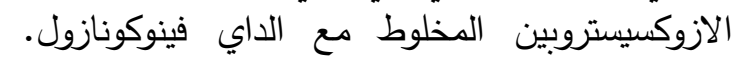

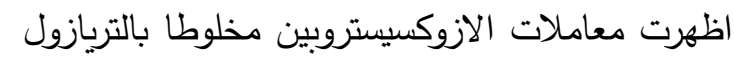

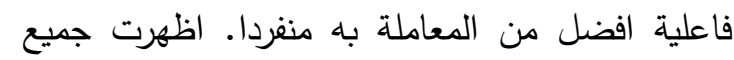

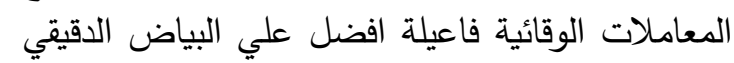

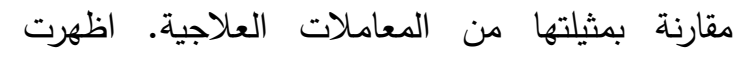
معاملات فوسفات الاحادي والثنائي البوتاسيوم فاعلية

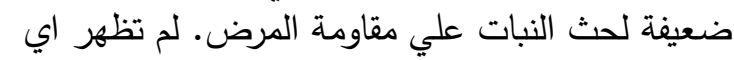
مظاهر للسمية النباتية علي النبات نتيجة مقات التئة استخدام المركبات المختبرة وقائيا او علاجيا.

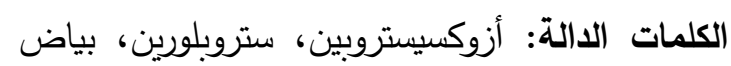
دقيقي، وقائي، علاجي، فاعلية، قرعيات الزوكينت

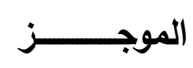

يهدف هذا البحث الى تقدير الفاعلية الوقائية

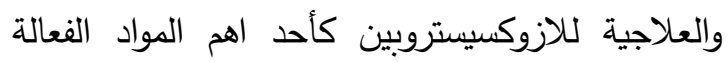

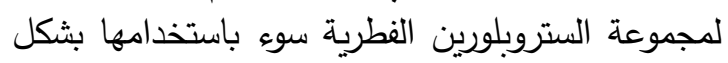

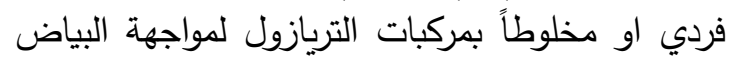

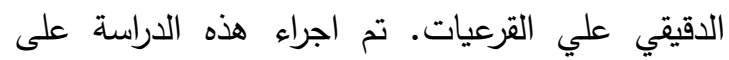

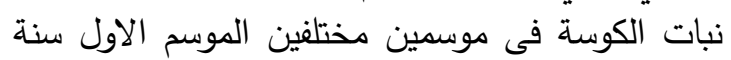
2015 في التربة الصفراء في منطقة ابو فئ غالب الاول

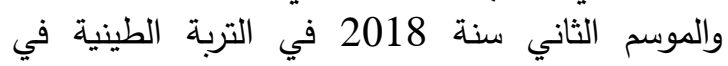
منطقة قها محافظة القليوبية. قد تم معاملة نباتات الكوسة في الموسم الاول بشكل علاجي بعد الصابة

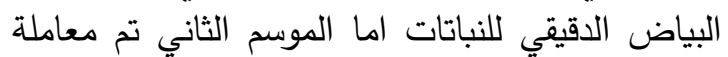

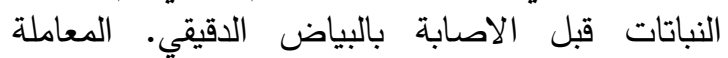

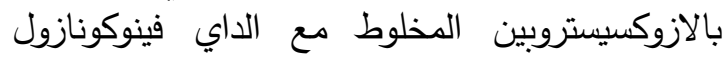

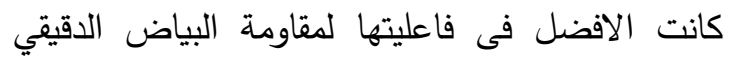

